International Journal of Social Science and Economic Research

ISSN: $2455-8834$

Volume: 05, Issue: 04 "April 2020"

\title{
RURAL NON-FARM EMPLOYMENT IN KARNATAKA: AN ANALYSIS OF DIFFERENT DIMENSIONS
}

\author{
Ravikumar C.N.
}

Assistant professor, Department of Economics, Government First

Grade College for Women, Chikkaballapur, Karnataka.

DOI: 10.46609/IJSSER.2020.v05i04.002 URL: https://doi.org/10.46609/IJSSER.2020.v05i04.002

\begin{abstract}
The RNFE play an important role in developing countries which are characterized by a set of problems such as mounting population pressure, diminishing land frontiers, small and fragmented land holdings and a high incidence of unemployment and poverty. The constitute and important category of income and provide supplementary employment to the poor households, especially during the slack season, reduce income inequalities, stabilize their income levels and minimize the adverse impact of urbanization etc. In determining the total employment and income status of the poor households, RNFS has a place of great significance in the rural economy. An analysis examining different dimensions of RNFE by region, gender, activities, age groups, level of education and size of landholdings de facto, helps policy makers and development practitioners in deciding about the type of policy intervention to tackle the longstanding problems such as unemployment, poverty and income inequality simultaneously. Against this background the present study has made an attempt to analyze the RNFE among social groups and regional Imbalances in Karnataka. The study is mainly based on primary data. Karnataka state is selected for the purpose of the present study. The total sample size of the study was 400 households. Simple statistical tools like percentage was employed for analysis of data. The main findings reveal that the growth and diversification of employment away from agriculture is not uniform within the state. There is a significant zonal disparity in the growth of agricultural as well as non-agricultural employment. Therefore, to reduce such zonal disparity, zonal specific developmental programmes should effectively be implemented in each zone of the State. So that the regional disparity can be reduced.
\end{abstract}

Keywords: Rural non-farm employment, Social-groups, Arid zone, Coastal zone 
International Journal of Social Science and Economic Research

ISSN: $2455-8834$

Volume: 05, Issue: 04 "April 2020"

\section{INTRODUCTION}

Diversification of rural economy has been at the central stage of development policy since the inception of planning era, in addition to raise agricultural productivity in India as elsewhere. The rural non-farm sector (RNFS) is increasingly being recognized as a potential source of employment, diversified and diffused economic development. With the capital intensive nature of current economic growth, generation of adequate employment opportunities has emerged as a key concern of policy makers. As agricultural sector ceased to absorb reasonable degree of labour force in India, RNFS has gained a great deal of attention as promise able source of employment and earnings. The RNFS, however, is a highly heterogeneous category (Singh, 2007).

A significant role played by the RNFS in the over-all development of rural economics is now well-recognized. Although the debate on agriculture induced diversification as the corner stone of the development of RNFS continues to attract a great deal of attention, many recent studies on urban-linkages of rural non-farm growth. Clearly point to the role of RNFS as an important link between industry and agriculture. In terms of employment generation, the role of RNFS in absorbing the labour, particularly in the context of the stagnant growth of employment in formal manufacturing sector, can hardly be overstressed. However, given the heterogeneity and diversity within the RNFS itself, there is a need to study the growth performance as well as labour absorption capacity of the sector in specific regional and sect oral contexts.

The RNFE play an important role in developing countries which are characterized by a set of problems such as mounting population pressure, diminishing land frontiers, small and fragmented land holdings due to dealing land, man ratio and a high incidence of unemployment and poverty. The constitute and important category of income and provide supplementary employment to the poor households, especially during the slack season, reduce income inequalities, stabilize their income levels and minimize the adverse impact of urbanization etc. In determining the total employment and income status of the poor households, RNFS has a place of great significance in the rural economy.

A shift in the structure of employment in favour of non-agricultural sector is considered to be an index of economic development. India was perhaps the only developing country where the proportion of the labour force dependent on agriculture remained nearly constant despite considerable increases in per capital incomes. Some studies in the early 1980s observed of fall in the proportion of workers engaged in agriculture related activities and an increase in the share of the non-agricultural sector (Krishnamurthy 1982, 1984: 2121-28: Visaria 1984). 


\section{International Journal of Social Science and Economic Research}

ISSN: $2455-8834$

Volume: 05, Issue: 04 "April 2020"

An analysis examining different dimensions of RNFE by gender, activities, age groups, level of education and size of landholdings de facto, helps policy makers and development practitioners in deciding about the type of policy intervention to tackle the long-standing problems such as unemployment, poverty and income inequality simultaneously. The economic growth process of the present industrialised countries shows a particular pattern of sectoral diversification in employment as well as income over time. Several studies (Fisher 1939; Clark 1940; Kuznets 1966; Cheneryand Syrquin 1975) on the growth process of the present industrialised economies point out that as economic growth takes place, the share of primary sector largely consisting of agriculture shows a decline in its relative contribution to national output, even though its absolute contribution to national output increases. The growth of primary sector contributes to the growth of secondary or industrial sector through its multiple linkages.

Since the 1970s, especially when the sustained decline in poverty incidence has been accompanied with a decline in proportion of workers in agriculture and a corresponding rise in rural non-agriculture, the growth of RNFE has become an important content of rural development paradigm. A considerable decline in the share of agriculture in national income accompanied with a marginal decline in the share of agricultural workers has resulted in a decline in the growth rate of relative productivity per worker in agriculture and substantial increase in the rural non-agricultural sector (Nagaraj 1990; Unni and Rani 2000; Madheswaran and Dharmadhikary 2000). This has created the ample scope for investment, and increase in production and employment opportunities in the rural non-agricultural sector in India. Consequently the growth of RNFE has been on the rise with varying degrees across general and activities over time.

In view of the above analytical framework, it is essential to address the following research issues; what type of the zones that have experienced a greater rise in male and female RNFE? Who has been shifting more to RNFE, whether men or women? Against this background the present study is designed with the following objectives.

\section{OBJECTIVES OF THE STUDY}

The objectives of the study are to:

$>$ Study the distribution of workers in RNFE among social groups by gender at different agro - climatic conditions;

$>$ Examine the distribution of workers in RNFE among social groups by activities at different agro - climatic conditions;

$>$ Offer policy guidelines for sustained growth of RNFE among social groups at different agro-climatic conditions. 
International Journal of Social Science and Economic Research

ISSN: $2455-8834$

Volume: 05, Issue: 04 "April 2020"

\section{DATA BASE AND METHODLOGY}

The study is mainly based on primary data. The primary data were collected by canvassing the structured interview schedules among the sample households engaged in rural non-farm activities in two districts of Karnataka, namely Bijapur (Arid zone) and Shimoga (Coastal zone).Multi-stage stratified random sampling technique, State as the first stage, Agro-climatic Zones as the second stage, districts as the third stage, taluks as the fourth stage, the villages as the fifth stage, and the households as the final or ultimate stage, was adopted for collection of the data among social groups. Karnatak State is selected for the purpose of present study. It is because the state which witnessed, of late, slow growth or even negative growth, in RNFE has been chosen for an in-depth study at different agro-climatic zonal level. The Karnataka state has been classified into four sub-regions by the Zonal planning Teams (ZPT); Arid zone; Semi-arid zone; Irrigated Zone; and, Coastal Zone.

Out of the four zones only two zones; namely Arid zone and Coastal zone were selected for the field study. It is because these zones have different types of soil topography, elevation and climate, rainfall, and employment pattern. From each agro-climatic zone, one district viz., Bijapur from arid zone and Shimoga from coastal zone were chosen .From each district, two taluks one advanced (Bijapur) and one backward (Indi) from Bijapur district and one advanced (Shimoga) and one backward (Sagara) from Shimoga district were chosen for the present study. At the fifth stage 8 villages from 4 selected taluks were selected on the basis of agro-climatic features, agricultural growth, rate of literacy the SC/ST population density, availability of infrastructure and proximity to urban areas

In the last stage the households were selected from the sample villages. For the selection of the sample households, a list of households with basic details was prepared in each of the sample village by a village census. Further, the sample households belonging mainly to SCs, STs and Others engaged in RNFE were randomly selected in each village of the study area. From each village. 50 households, of which 12 from SCs, 8 from STs and 30 from others were selected with a view to ensuring more representation from the others caste community as the significant proportion is found to be higher and persistent. The total sample size of the study was 400 households consisting of 50 households each from 8 villages.

\section{RURAL NON-FARM EMPLOYMENT BY SOCIAL GROUPS}

Non-farm employment is divided into three categories: regular employment (generally salaried), casual employment (daily wage) and self-employment/own enterprise activities. This distinction is intended to reflect to some extent the very different characteristics of non-farm activities in rural areas - characteristics that are important in terms of defining the desirability of such jobs. A 
general typology that appears to resonate with findings from many village studies is that regular non-farm employment is typically highly sought-after in rural areas as it is associated not only with high incomes, but crucially also with a degree of stability. Non-farm self-employment activities, but whether they are of the former or latter variant generally depends on the amount of capital resources that can be brought to the activity. Casual non-farm wage employment is generally thought to be less demeaning to a workers than agricultural wage labour, but returns may be only marginally higher and the nature of the work may be both physically demanding as well as hazardous (construction, rickshaw pulling, industrial workshops, etc) (Kusugal, 2011).

\subsection{Self - Employment in Rural Non-Agriculture (SERNA)}

The growth of RNFE is regarded as one of the important strategies for sustained reduction in poverty and income inequality in most of the developing countries. Self-employment in the rural non-agricultural sector includes, petty shop, vegetable vending shop, hotel business, tailoring, cloth merchant, match and basket weaving, beedi rolling etc., which give them regular employment and sustained income. Given the stock of capital assets, for a large number of the sample households, the rural non-agricultural self-employment is one of the important livelihood strategies. The data provided in Table 1 reveal that 33.9 percent of the main workers were involved in the rural non-agricultural self-employment in the study region as a whole.

Table 1: Distribution of Main Workers Involved in Self-Employment in Non-Agriculture by Social Groups

\begin{tabular}{|c|c|c|c|c|c|c|}
\hline \multirow[t]{2}{*}{ Social groups } & \multicolumn{3}{|c|}{$\begin{array}{l}\text { Workers involved in Self- } \\
\text { employment in non Agriculture }\end{array}$} & \multicolumn{3}{|c|}{ Percentage to main workers } \\
\hline & Males & Females & All & Males & Females & All \\
\hline \multicolumn{7}{|l|}{ Arid zone } \\
\hline SCs & 31 & 24 & 55 & 39.2 & 42.1 & 40.4 \\
\hline STs & 20 & 11 & 31 & 35.7 & 37.9 & 36.5 \\
\hline Others & 125 & 35 & 160 & 60.7 & 41.2 & 55.0 \\
\hline Total & 175 & 70 & 246 & 51.3 & 41.0 & 48.0 \\
\hline \multicolumn{7}{|l|}{ Coastal zone } \\
\hline SCs & 6 & 5 & 11 & 7.1 & 5.5 & 6.3 \\
\hline STs & 8 & 2 & 10 & 16.0 & 3.6 & 9.4 \\
\hline Others & 91 & 13 & 104 & 42.1 & 15.1 & 34.4 \\
\hline Total & 105 & 20 & 125 & 29.9 & 8.6 & 21.4 \\
\hline
\end{tabular}


International Journal of Social Science and Economic Research

ISSN: $2455-8834$

Volume: 05, Issue: 04 "April 2020"

\begin{tabular}{||l|c|c|c|c|c|c||}
\hline SCs & 37 & 29 & 66 & 22.6 & 19.6 & 21.2 \\
\hline STs & 28 & 13 & 41 & 26.4 & 15.3 & 21.5 \\
\hline Others & 216 & 48 & 264 & 51.2 & 28.1 & 44.5 \\
\hline Total & 281 & 90 & 371 & 40.6 & 22.3 & 33.9 \\
\hline
\end{tabular}

Source: Primary Survey.

Going by social groups, it was awfully lower in the case of SCs/STs as compared to Others. This can be attributed to limited access to skill/knowledge, experience, capital and also to social exclusion in the country side. Human capital discrimination continued to exist against SCs/STs in favour of Others (Biradar 2004). The proportion of workers in the rural non-agricultural selfemployment was found to be higher for males (51.3 percent) as compared to that of females (41.0 percent) in arid zone. Similarly, in the case of coastal zone the proportion of workers in the rural non-agricultural self-employment was found to be higher for males (29.9 percent) as compared to that of females (8.6 percent). Similar trend by and large was also observed across social groups.

\subsection{Casual Wage Employment in Rural Non-Agriculture (CWERNA)}

Casual wage employment in the rural non-agricultural sector includes manual works in construction, hotel business, vegetable vending shops, cloth merchants, petty shops, garage and repair centres, any other such dead-end contractual/temporary jobs prevailed in the countryside. The workers in these activities are paid relatively more wages and do not experience more employment seasonality as compared to the workers involved in agriculture.

The data presented in Table 2 indicate that the proportion of workers in casual wage employment in the rural non-agricultural sector was estimated at 33.7 percent among the sample household main workers. The availability of casual wage employment in the rural non-agricultural sector was not similar across social groups, gender and zones. The proportion workers having access to casual wage employment in the rural non-agricultural sector was found to be significantly higher in the case of SCs/STs as compared to Others.

The proportion of workers in the casual wage employment in rural non-agriculture sector was found to be higher for males (10.6 percent) as compared to that of females (2.3 percent) in arid zone. However, interestingly in the case of coastal zone the opposite trend was observed that the proportion of workers in the casual wage employment in the rural non-agriculture sector was found to be much higher for females ( 82.8 percent)s as compared to that of males (38.7), because beedi rolling is a major casual wage employment in rural non-agriculture sector for females in this zone. A similar trend was also observed across social groups. The growth of such 
employment was not significantly higher in the sample villages of arid zone than those of in coastal zone. It is clear from the above analysis that the members of Other households as compared to SCs/STs, female workers as against male workers and the workers in the sample villages of arid zone as compared to coastal zone had limited access to casual wage employment in the rural non-agricultural sector.

\section{Table 2: Distribution of Main Workers in Csual Wage Employment in Rural Non-Agriculture by Social Groups}

\begin{tabular}{|c|c|c|c|c|c|c|}
\hline \multirow[t]{2}{*}{ Social groups } & \multicolumn{3}{|c|}{$\begin{array}{c}\text { Workers in Casual wage } \\
\text { employment in non Agriculture. }\end{array}$} & \multicolumn{3}{|c|}{ Percentage to main workers } \\
\hline & Males & Females & All & Males & Females & All \\
\hline \multicolumn{7}{|l|}{ Arid zone } \\
\hline SCs & 15 & 1 & 16 & 19.0 & 1.8 & 11.8 \\
\hline STs & 5 & 2 & 7 & 8.9 & 6.9 & 8.2 \\
\hline Others & 16 & 1 & 17 & 7.8 & 1.2 & 5.8 \\
\hline Total & 36 & 4 & 40 & 10.6 & 2.3 & 7.8 \\
\hline \multicolumn{7}{|l|}{ Coastal zone } \\
\hline SCs & 58 & 73 & 131 & 68.2 & 80.2 & 74.4 \\
\hline STs & 25 & 49 & 74 & 50.0 & 87.5 & 69.8 \\
\hline Others & 53 & 71 & 124 & 24.5 & 82.6 & 41.1 \\
\hline Total & 136 & 193 & 329 & 38.7 & 82.8 & 56.3 \\
\hline \multicolumn{7}{|l|}{ All } \\
\hline SCs & 73 & 74 & 147 & 44.5 & 50.0 & 47.1 \\
\hline STs & 30 & 51 & 81 & 28.3 & 60.0 & 42.4 \\
\hline Others & 70 & 71 & 141 & 16.6 & 41.5 & 23.8 \\
\hline Total & 172 & 197 & 369 & 24.9 & 48.8 & 33.7 \\
\hline
\end{tabular}

Source: Primary Survey

\subsection{Regular salaried/wage Employment}

Regular salaried /wage employment is another less accessible livelihood strategy of the sample households. In the present study, the activities included in this category are: driver, stenographer, teacher, Police, Nurse, attender, clerk, conductor, hatti gold company workers, hotel manager and etc., and their services are confirmed to be on regular basis. The data presented in the Table 3 show that the proportion of workers engaged in regular salaried/wage employment in the nonagricultural sector was estimated to be 13.7 percent of total main workers. Across social groups; 
it has been observed that the proportion of workers was significantly higher in the case of Others as compared to SCs/STs. Going by gender, it was found to be far less in respect of females vis-àvis male workers. Access to such activities was quite limited in the sample villages of arid zone, as compared to that of coastal zone, especially in the case of SCs/STs and female workers. On our discussion held with the sample households, especially in the case of SCs/STs, it was reported that access to such activities was constrained mainly due to lack of human capital, social networks, Political influence, etc.

Table 3: Distribution of Main Workers in Regular Salaried / Wage Employment by Social Groups

\begin{tabular}{|c|c|c|c|c|c|c|}
\hline \multirow[t]{2}{*}{ Social groups } & \multicolumn{3}{|c|}{$\begin{array}{l}\text { Workers in Regular salaried/wages } \\
\text { Employment. }\end{array}$} & \multicolumn{3}{|c|}{ Percentage to main workers } \\
\hline & Males & Females & Total & Males & Females & Total \\
\hline \multicolumn{7}{|l|}{ Arid zone } \\
\hline SCs & 14 & 1 & 15 & 17.7 & 1.8 & 11.0 \\
\hline STs & 5 & 1 & 6 & 8.9 & 3.3 & 7.1 \\
\hline Others & 28 & 3 & 31 & 13.6 & 3.5 & 10.7 \\
\hline Total & 47 & 5 & 52 & 13.8 & 2.9 & 10.6 \\
\hline \multicolumn{7}{|l|}{ Coastal zone } \\
\hline SCs & 14 & 7 & 21 & 16.5 & 7.7 & 11.9 \\
\hline STs & 8 & 3 & 11 & 16.0 & 5.4 & 10.4 \\
\hline Others & 53 & $\overline{13}$ & 66 & 24.5 & 15.1 & 21.9 \\
\hline Total & 75 & 23 & 98 & 21.4 & 9.9 & 16.8 \\
\hline \multicolumn{7}{|l|}{ All } \\
\hline SCs & 28 & 8 & 36 & 17.1 & 5.4 & 11.5 \\
\hline STs & 13 & 4 & 17 & 12.3 & 4.7 & 8.9 \\
\hline Others & 81 & 16 & 97 & 19.2 & 9.4 & 16.4 \\
\hline Total & 122 & 28 & 150 & 17.6 & 6.9 & 13.7 \\
\hline
\end{tabular}

Source: Primary Survey

\section{RURAL NON-FARM EMPLOYMENT BY STATUS OF EMPLOYMENT, ACTIVITIES AND SOCIAL GROUPS}

Table 4 presents the data on distribution of worker by status of employment in rural nonagriculture, activities and social groups. The data indicate that, across employment status, the proportion of workers was found to be quite significant in self-employment, followed by casual 
International Journal of Social Science and Economic Research

ISSN: 2455-8834

Volume: 05, Issue: 04 "April 2020"

wage employment as compared to regular salaried employment. The proportion of RNFE workers was estimated at 41.7 percent, 41.5 percent and16.9 percent in the case of selfemployment, casual wage, and regular salaried employment, respectively.

\subsection{Self-Employment in Rural Non-Agriculture}

Going by activities among social groups in the case of self-employment in rural non-agriculture, the proportion of workers was found to be quite higher in trade, hotel and business followed by tailoring, rural artisans, other services and manufacturing and repair in all the social groups viz., SCs/STs and Others both in arid and coastal zones and more so in arid zone. The proportion of workers engaged in self-employment in rural non-agriculture activities at aggregate level was estimated at 21.9 percent, 8.3 percent, 5.3 percent, 4.9 percent and 1.2 percent in the case of trade, hotel and business, tailoring, rural artisans, other services and manufacturing and repair, respectively. A similar trend by and large was also observed across social groups and zones.

\subsection{Casual Wage Employment in Rural Non-Agriculture}

In the case of casual wage employment in rural non-agriculture the proportion of workers was found to be quite significant in beedi rolling followed by construction, other services, trade, hotel, and business, rural artisans and manufacturing and repair in all the social groups viz., SCs/STs and Others. The proportion of workers involved in casual wage employment in rural non-agriculture activities at the aggregate level was estimated at 20.0 percent, 9.1 percent, 8.4 percent 2.6 percent, 0.8 percent and 0.6 percent in the case of beedi rolling, trade, hotel and business, rural artisans and manufacturing and repair, respectively.

\subsection{Regular Salaried Employment}

In the case of regular salaried/wage employment the proportion of workers was found to be quite higher in private sector as compared to public sector in all the social groups viz., SCs/STs and Others. The proportion of the workers engaged in regular salaried / wage employment at the aggregate level was estimated at 13.4 percent and 3.5 percent in the case of private and public sector, respectively. 
Table 4: Distributions Workers by Status of Employment in Rural Non-Agriculture by Activities and Social Groups (Percent)

\begin{tabular}{|c|c|c|c|c|c|c|c|c|c|c|c|c|c|c|c|c|c|}
\hline \multirow[b]{2}{*}{$\begin{array}{l}\text { Socia } \\
1 \\
\text { group } \\
\mathrm{S}\end{array}$} & \multicolumn{6}{|c|}{ Self-employment in non-Agriculture } & \multicolumn{7}{|c|}{ Casual Wage Employment in non-Agriculture } & \multicolumn{3}{|c|}{ Regular Salaried } & \multirow[b]{2}{*}{$\begin{array}{l}\text { Gran } \\
\mathrm{d} \\
\text { Total }\end{array}$} \\
\hline & 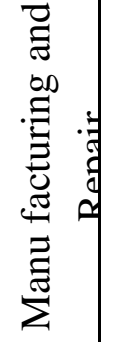 & 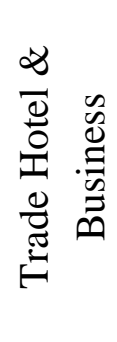 & 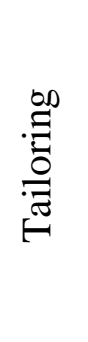 & 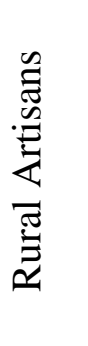 & 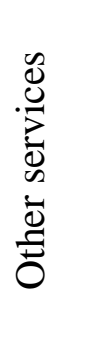 & 䒿 & 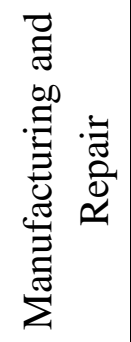 & 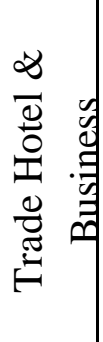 & 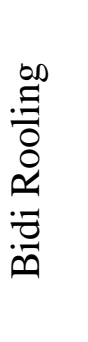 & 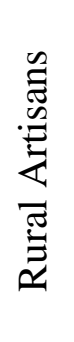 & 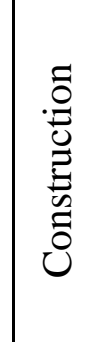 & 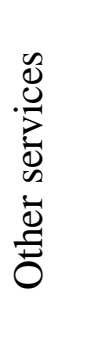 & 퓽 & 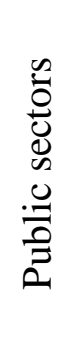 & 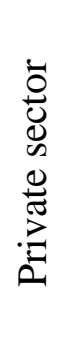 & $\stackrel{\frac{\pi}{0}}{\ominus}$ & \\
\hline \multicolumn{18}{|c|}{ Arid zone } \\
\hline SCs & -- & 20.9 & 22.1 & 12.8 & 8.1 & 64.0 & 1.2 & 1.2 & -- & -- & $\begin{array}{c}12 . \\
8\end{array}$ & 3.5 & 18.6 & 7.0 & $\begin{array}{c}10 . \\
5\end{array}$ & 17.4 & 100.0 \\
\hline STs & 6.8 & 36.4 & 18.2 & -- & 9.1 & 70.5 & -- & -- & -- & -- & 9.1 & 6.8 & 15.9 & 4.5 & 9.1 & 13.6 & 100.0 \\
\hline $\begin{array}{l}\text { Other } \\
\mathrm{s}\end{array}$ & 1.9 & 36.1 & 16.8 & 14.4 & 7.7 & 76.9 & 0.5 & 0.5 & -- & 1.9 & 3.4 & 1.9 & 8.2 & 8.2 & 6.7 & 14.9 & 100.0 \\
\hline Total & 2.1 & 32.2 & 18.3 & 12.1 & 8.0 & 72.8 & 0.6 & 0.6 & -- & 1.2 & 6.5 & 3.0 & 11.8 & 7.4 & 8.0 & 15.4 & 100.0 \\
\hline \multicolumn{18}{|c|}{ Coastal zone } \\
\hline SCs & -- & 2.5 & 1.2 & 1.8 & 1.2 & 6.7 & -- & 0.6 & 37.4 & -- & $\begin{array}{c}20 . \\
9\end{array}$ & 21.5 & 80.4 & 1.2 & $\begin{array}{c}11 . \\
7\end{array}$ & 12.9 & 100.0 \\
\hline STs & 1.1 & 8.4 & -- & 1.1 & -- & 10.5 & 2.1 & 4.2 & 49.5 & -- & 6.3 & 15.8 & 77.9 & -- & $\begin{array}{c}11 . \\
6\end{array}$ & 11.6 & 100.0 \\
\hline Other & 1.0 & 25.2 & 3.4 & 0.7 & 5.1 & 35.4 & 0.3 & 5.4 & 23.8 & 1.0 & 6.5 & 5.1 & 42.2 & 1.4 & 21. & 22.4 & 100.0 \\
\hline
\end{tabular}


International Journal of Social Science and Economic Research

ISSN: 2455-8834

Volume: 05, Issue: 04 "April 2020"

\begin{tabular}{||l|c|c|c|c|c|c|c|c|c|c|c|c|c|c|c|c|c||}
\hline \hline s & & & & & & & & & & & & & & 1 & & \\
\hline Total & 0.7 & 15.6 & 2.2 & 1.1 & 3.1 & 22.6 & 0.5 & 3.8 & 32.2 & 0.5 & $\begin{array}{c}10 . \\
7\end{array}$ & 11.8 & 59.6 & 1.1 & 16. & 17.8 & 100.0 \\
7 &
\end{tabular}

Note: Figures in parenthesis are actual data

Source: Primary Survey. 
International Journal of Social Science and Economic Research

ISSN: $2455-8834$

Volume: 05, Issue: 04 "April 2020"

\section{CONCLUSIONS AND POLICY IMPLICATIONS}

It has been observed from the forgoing analysis that a majority of main workers were involved in the rural non-agricultural self-employment in the study region as a whole. Going by social groups, it was awfully lower in the case of SCs/STs as compared to Others. This can be attributed to limited access to skill/knowledge, experience, capital and also to social exclusion in the country side. Human capital discrimination continued to exist against SCs/STs in favour of Others.

The growth and diversification of employment away from agriculture is not uniform within the state. There is a significant zonal disparity in the growth of agricultural as well as nonagricultural employment. Therefore, to reduce such zonal disparity, zonal specific developmental programmes should effectively be implemented in each zone of the State. So that the regional disparity can be reduced.

Arid zone has not much diversified its economic activities within and outside the agriculture as compared to coastal zone. Therefore, to promote agricultural allied activities such as dairy, sheep rearing poultry farming etc., in agriculture and petty manufacturing activities, trade, hotel and business and service related activities in rural non-farm sector should be promoted by initiating special programmers in arid zone. So that the regional disparity can be reduced and out migration of rural workforce can also be arrested.

Households that belong to scheduled castes/tribes or that belong to the general category are less likely to participate in unskilled wage labour compared to households that are members of other backward classes. This suggests that households that belong to other backward classes find themselves in unfavorable conditions relative to other households when it comes to accessing high skilled wage employment. Job reservation has been seen as the most important of the public concessions towards scheduled castes/tribes in India and there is demand to extend reservation to persons who belong to other backward classes. Our results suggest that if the job reservation policy is to be extended beyond the scheduled caste/tribes, then households from the other backward classes may have a strong case.

The government should allocate a larger proportion of resources to provide the demand driven infrastructure facilities such as all weather road, marketing net works, farming institutions, education, health care systems, electricity and the like, provision of such infrastructure facilities would certainly generate externalities, which at as incentives for rural entrepreneurs to initiate innovative programmes in non-farm sector. So that sustainable development of non-farm sector can be ensured. 
International Journal of Social Science and Economic Research

ISSN: $2455-8834$

Volume: 05, Issue: 04 "April 2020"

\section{REFERENCES}

Anderson and Leiserson (1980): "Rural Non-farm Employment in Developing Countries", Economic Development and Cultural Change, 28(2).

Basant, Rakesh (1998): "Diversification of Economic Activities in Rural Gujarat: Some Evidence at the Micro Level", in Basant, Rakesh. B.L. Kumar and Parthasarathy (ed.) Non-Agricultural Employment in Rural India: The Case of Gujarat, (New Delhi: Rawat Publications).

Biradar, R. R. (2009): "Rural Non-Agricultural Employment in India: Analysis of its Determinants and Impact of Poverty and Inequality (New Delhi: Concept Publishing Company).

Biradar, R. R. and S. T. Bagalkoti (2001): "Changing Facets of Employment in Rural India: Emerging Issues and Challenges", Indian Journal of Agricultural Economics, 56(3).

Chadha, G. K. (2002): "Rural Non-Farm Employment in India: What Does Recent Data Experience Teach Us", The Indian Journal of Labour Economics, 45 (4).

Chandrasekhar, C. P. (1993): "Agrarian Change and Occupational Diversification: NonAgricultural Employment and Rural Development", The Journal of Peasant Studies, 20 (2).

Chenery, B. H. and M. Syrquin (1975): Patterns of Development 1950-1970, (New Delhi: Oxford University Press).

Clark, Colin (1940): The Conditions of Economic Progress, (London: Macmillan).

Fisher, A.G.P (1939): "Production, Primary, Secondary and Tertiary", Economic Record, Vol. 15: 24-38.

Krishnamurthy, J. (1984): "Changes in the Indian Workforce". Economic and Political Weekly, $19(50)$.

Kusugal N.S.(2011): Rural Non-Farm Employment among Social Groups in Karnataka: A Household Level Study at Different Agro-Climatic Zones, Unpublished Ph.D. Thesis Submitted to Karnataka University, Dharwad. 
Kuznets, Simon (1966): Modern Economic Growth: Rate, Structure, Spread, (Yale: University Press).

Madheswaran, S. and Amita Dharmadikhary (2000): "Income and Employment in Service Sector in India", The Indian Journal of Labour Economics, 43 (4).

Nagaraj, R. (1990): "Growth Rate of India's GDP, 1950-51 to 1987-88: Examination of Alternative Hypothesis", Economic and Political Economy, June 30.

Singh,Surjit (2007): Rural Non-Farm Sector in India: Experience and Perspective from the Grassroots, Institute of Development Studies, New Delhi.

Unni, Jeemol and Uma Rani (2000): "Globalisation, Information Techcnology Revaluation and Service Sector in India", The Indian Journal of Labour Economics, 43 (4). 